\title{
Luz y oscuridad: apuntes sobre el concubinato de clérigos en Castilla (siglos XI-XV)*
}

\author{
Ana E. Ortega Baún ${ }^{1}$ \\ Universidad de Valladolid \\ anae.ortegabaun@hotmail.com
}

RESUMEN: El objetivo de esta investigación es destacar la importancia de algunos aspectos no muy conocidos del concubinato de clérigos. La persecución contra estos clérigos existía ya antes del Concilio de Valladolid de 1228. La gran novedad de este Concilio no van a ser las medidas contra los clérigos sino la creación de preceptos para volver invisibles y dificultar la vida a sus barraganas e hijos, una tendencia que seguirá en los siguientes siglos. El estudio de los castigos dirigidos a estos dos últimos grupos a través de sínodos, concilios, cortes y sobre todo documentación de archivo permite acercarse a su cumplimiento y efectividad. Este examen arroja varias sorpresas como que las barraganas de clérigos ya eran socialmente mal vistas a mediados del XIII, que los reyes neutralizaron parte de las medidas eclesiásticas en diferentes momentos y lugares y que la persecución por parte de las autoridades civiles de las barraganas eclesiásticas fue real desde finales del siglo XIV.

\section{PALABRAS CLAVE: sexualidad; concubinato eclesiástico; concubina de clérigo; manceba de clérigo; barragana de clérigo; hijo de clérigo.}

\section{Light and darkness: notes on clerical concubinage in Castile (eleventh-fifteenth cen- turies)}

ABSTRACT: The objective of this research is to highlight some aspects of clerical concubinage. Clerical concubinage was persecuted before the Council of

* Este artículo fue galardonado con el XVI Premio Medievalismo, otorgado por la Sociedad Española de Estudios Medievales (SEEM) en su edición del año 2015.

Citas de archivos: AGS (Archivo General de Simancas).

${ }^{1}$ ORCID iD: https://orcid.org/0000-0001-9295-8467. 


\begin{abstract}
Valladolid in 1228. What was new about this council was not the punishment inflicted on clergymen, but the measures taken to render their partners and offspring invisible and make life difficult for them, a trend that would continue over the following centuries. The study of the measures adopted against partners and children from the documentation of synods, councils, courts and archives enables us to explore their compliance and effectiveness. Surprising conclusions are also revealed. Clerics' concubines were considered socially undesirable as early as the first half of the thirteenth century; monarchs neutralized a part of the measures adopted against partners and children at different times and places; and clerics' concubines were persecuted by the civil authorities from the end of the fourteenth century.
\end{abstract}

KEY WORDS: sexuality; priest's partner; clerics' concubines; priest's child; clerical families; clerical concubinage.

CÓMO CITAR ESTE ARTÍCULO/CITATION: Ortega Baún, Ana E., «Luz y oscuridad: apuntes sobre el concubinato de clérigos en Castilla (siglos XI-XV)», Hispania, 78/258 (Madrid, 2018): 11-38. https://doi.org/103989/hispania.2018.001.

\title{
INTRODUCCIÓN
}

En las últimas décadas, el concubinato de clérigos en la Edad Media o las relaciones que entablaron estos con mujeres a semejanza de parejas casadas, ha sido estudiado de forma muy atenta. Imprescindibles son los trabajos para la Corona castellana de Emilio Gacto, José Sánchez Herrero, Peter Linehan, Ricardo Córdoba de la Llave, Federico R. Aznar Gil y Ana Arranz Guzmán entre otros $^{2}$. Los esfuerzos se han centrado en demostrar la existencia de este fenómeno, en enumerar sus características y en medir su aceptación o condena, así como en describir y valorar el éxito de parte de las normas que contra él se erigieron. Pero pese a esta dedicación todavía hay puntos en penumbra que se pueden explorar mediante nuevas fuentes históricas. La insuficiente atención que se ha prestado a los sínodos leoneses y castellanos anteriores al Concilio de Valladolid de 1228 ha dificultado ver que la persecución a estos clérigos ya existía con anterioridad con medidas muy parecidas. Pero sobre todo ha impedido valorar las novedades creadas por este concilio y que van a afectar a barraganas e hijos durante los siguientes siglos. Son presiones de tipo social y económico para hacer imposible la vida de estas familias de clérigos. Gracias a la documentación de archivo podemos saber cuál fue su alcance, como tam-

2 GACTO, 1969; 41 (Madrid, 1971). SÁNCHEZ HERRERO, 1976; 1978; 5 (Durango, 2008). LINEHAN, 1975. CÓRDOBA, 16 (Barcelona, 1986). AZNAR, 55/145 (Salamanca, 1998). ARRANZ, 2008a: 227-262; 21 (Madrid, 2008b). 
bién cuál fue el papel de un tercer protagonista. La Corona va a actuar en algunos momentos contra los intereses de castidad de la Iglesia y otros a favor de ellos, ayudando o castigando a estas familias.

La lucha contra el concubinato de clérigos entre los siglos XI y XV es un fenómeno que interesa particularmente a la historia de la sexualidad. No hay que olvidar que impedía que los legos aceptasen la moral sexual eclesiástica y que ante la imposibilidad de eliminarlo, la Iglesia decidió actuar solo contra los casos menos discretos y por tanto los que más daño hacían a la aceptación de la moral sexual.

\section{LA VIDA SEXUAL DEL CLERO SECULAR: IMPORTANCIA, NORMAS, TRAMPAS}

En la Edad Media la Iglesia encuentra un grave problema dentro de sus propias filas para imponer su moral sexual. El clero secular de órdenes mayores tiene una vida sexual que no oculta. Sus parejas e hijos viven con ellos o su existencia es conocida ${ }^{3}$. Estos clérigos concubinarios suponen un gran problema ya que con su comportamiento dificultan que los legos acaten la norma de que el sexo sólo tiene cabida dentro del matrimonio. Por ello son acusados de dar mal ejemplo, disminuir la devoción de los legos y mostrar indiferencia hacia la fe y la moral católica ${ }^{4}$. Su estilo de vida resta eficacia a todo lo que se predica $^{5}$. ¿Qué cristiano sin casar va a aceptar que no puede mantener relaciones sexuales cuando solteros consagrados como el párroco o el obispo tienen varios hijos incluso de diferentes mujeres? La contradicción entre lo que dice la moral y lo que hace un clérigo puede no solo llevar a sus fieles a ignorar lo que se predica pese a escucharlo y entenderlo, sino a que tomen como ejemplo su vida pecaminosa ${ }^{6}$. Algunos lo harán conscientes del desafío a la moral católica pero otros no. A inicios del siglo XVI el obispo de Burgos comenta que puesto que los prelados de la Iglesia tienen mancebas e hijos públicamente y esta costumbre se extiende a todo el clero, los seglares creen que no es pecado el sexo entre personas legas solteras ${ }^{7}$. Acabar con el concubinato público eclesiástico es necesario para que los legos acepten la moral sexual católica y para que no tengan dudas en saber qué es pecado y qué no.

Pero eliminar este fenómeno es muy difícil. Los sacerdotes medievales nunca prometen guardar castidad, lo que hace que no se sientan obligados a respe-

3 ARRANZ, 21 (Madrid, 2008b): 31-32.

${ }^{4}$ GARCÍA, 2010, Jaén, sínodo de 1478: 562; 1997, Palencia, sínodo de 1500: 559; 2011, Cuenca, sínodo de 1531: 473.

5 AZNAR, 55/145 (Salamanca, 1998): 516-518.

6 TEJADA, 1861, Peñafiel, Concilio de 1302: 435-436.

${ }^{7}$ AZNAR, 55/145 (Salamanca, 1998): 505. 
tarla. Las palabras de Clemente Sánchez de Vercial a inicios del siglo XV son claras al hablar de esta falta de compromiso: los subdiáconos deben vivir castamente porque así lo ordena la Iglesia, pero no porque la castidad sea consustancial a la orden ${ }^{8}$. A esto hay que añadir que buena parte de la clerecía europea no creía que el celibato o la castidad fuese algo propio de su condición ${ }^{9}$. Durante toda la Edad Media el celibato clerical fue objeto de numerosas discusiones teológicas ${ }^{10}$. Es más, algunas medidas tomadas desde las mismas instituciones eclesiásticas no ayudaban a que la castidad se valorase. En 1452 una canonjía en León queda libre porque el titular no se ha separado de su compañera, pero al próximo beneficiario sólo se le pide que no haya tenido concubina pública tres meses antes de ocuparla y que no la tenga dos meses después ${ }^{11}$. Y no hay que olvidar que los obispos podían ser auténticos reformadores, pero en su mayoría parece que fueron tolerantes, negligentes, se encontraban en situaciones similares, querían equipararse a los nobles o buscaban una forma de reafirmar su masculinidad ${ }^{12}$.

Las dificultades de la Iglesia para imponer la castidad entre el clero de órdenes mayores eran muchas. El modo en el que orientó algunas de sus medidas para lograrlo es de lo más revelador. La más conocida es la persecución del clérigo concubinario público ${ }^{13}$. El adjetivo "público» no es baladí sino un vocablo central en la historia del concubinato eclesiástico castellano. Los hay que tienen una concubina o barragana o manceba, como también las llama la documentación, públicamente y otros que las tienen ocultas o secretas. La diferencia es importante porque solo contra las primeras parejas se centran las normas conciliares y sinodales. Una relación de concubinato público es aquella que posee cierta estabilidad y, además, es conocida por los demás miembros de la comunidad, siendo indiferente que vivan o no juntos ${ }^{14}$. La publicidad de la relación se puede determinar de varias maneras. La más sencilla es que el clérigo no encubra la relación y se comporte ante el resto de la comunidad como si fuese un lego más con su pareja y/o con los hijos habidos en ella. Son relaciones que o no se esconden o no se pueden esconder. En otras ocasiones y pese a la discreción de la pareja, alguien que sospecha los denuncia y acaban confesando sin más ante los provisores su falta, o bien la rela-

8 SÁNCHEZ DE VERCIAL, 1475?: 184r.

9 AZNAR, 55/145 (Salamanca, 1998): 545.

${ }^{10}$ MURO, 20 (Sevilla, 1993): 267.

11 ÁLVAREZ, 2007: 683, asiento 2609.

12 ARRANZ, 21 (Madrid, 2008b): 31-32. Sobre su equiparación con la nobleza ver FERNÁNDEZ CONDE, 2011: 104-107.

${ }^{13}$ Desde mi punto de vista el mejor trabajo al respecto es el de AZNAR, 55/145 (Salamanca, 1998).

14 AZNAR, 55/145 (Salamanca, 1998): 510. 
ción es probada mediante testigos, o fueron anteriormente ya condenados ${ }^{15}$. Pero al castigar sólo a estos las normas crean una trampa. En ningún momento se impide a los clérigos que vivan su vida sexual con discreción. Si lo hacen así nunca serán castigados, puesto que los sínodos y concilios nunca van a contemplar su situación a no ser que se descubra. Esto que podría ser censurable a nuestros ojos no lo es para Hernando de Talavera en el siglo XV. Apoyándose en una larga tradición, en su confesional dicta que no es pecado que un clérigo sea lujurioso en secreto y guarde las apariencias en público. Pese a lo reprobable de su comportamiento, sería más grave si fuese sincero y no se comportarse ante los demás como un buen sacerdote ${ }^{16}$.

La Iglesia castellana, empujada por la necesidad de que su moral sexual fuera aceptada, se centró en castigar solo a los concubinarios públicos y no a los demás. Enfocó sus esfuerzos en quienes la hacían más daño, unas medidas que ya aparecen en el siglo XII y que van a persistir a lo largo del tiempo sin afectar a los concubinarios secretos.

\section{LAS MEDIDAS CONTRA EL CONCUBINATO DE CLÉRIGOS ANTES Y DESPUÉS DE 1228}

Cuando en el siglo XI la reforma gregoriana se pone en marcha, uno de sus objetivos es obligar a vivir en castidad a los clérigos de órdenes mayores. Para ello el primer paso que va a dar será prohibirles el acceso al matrimonio. $\mathrm{Y}$ es que podían casarse pese a que estas uniones eran contrarias al derecho eclesiástico pero no inválidas ${ }^{17}$. Nicolás II en un Concilio celebrado en 1059 prohibió por primera vez el matrimonio a los presbíteros ${ }^{18}$. Poco tiempo después, en 1068, llegan las primeras medidas a la península Ibérica. El Concilio de Gerona dicta que los ordenados «in sacris» que estén casados o tengan concubina sean expulsados del coro, desprovistos de sus beneficios eclesiásti$\cos$ y obligados a situarse en la iglesia con los legos ${ }^{19}$. Se trata de castigos económicos y de imagen social al perder el beneficio y ser degradados de su lugar en la Iglesia. Diez años después y en el mismo lugar, la pena aumenta al perder también su grado eclesiástico ${ }^{20}$. Más contundentes van a ser las palabras del primer Concilio de Letrán celebrado en 1123 en el que Calixto II declara nulos los matrimonios contraídos por miembros de las órdenes mayo-

15 PÉREZ, 2002: 40 y 254-255.

16 TALAVERA, 1911: 30.

${ }^{17}$ SÁNCHEZ HERRERO, 5 (Durango, 2008): 127.

18 SÁNCHEZ HERRERO, 5 (Durango, 2008): 127.

19 AZNAR, 55/145 (Salamanca, 1998): 506.

${ }^{20}$ AZNAR, 55/145 (Salamanca, 1998): 506-507. 
res $^{21}$. Al calor de la primera reunión lateranense, el Concilio de Burgos de 1127 decreta que todos los clérigos de órdenes mayores que estén casados o tengan concubina pública, sean despojados de su grado y de su beneficio eclesiástico ${ }^{22}$. El siguiente Concilio que nos interesa, el de Palencia del año 1129, introduce un importante elemento. Por primera vez las disposiciones exigen que las parejas de los clérigos que vivan públicamente con ellos sean castigadas expulsándolas de las casas que comparten, aunque no se puede desechar la idea de que lo fueran de la población ${ }^{23}$. Pese a ser el primer castigo directo dirigido a ellas, no hemos de olvidar que solidariamente sufrían con las penas dirigidas a sus compañeros.

En 1139 el II Concilio de Letrán da el golpe de gracia a los matrimonios de clérigos al declararlos incompatibles con las órdenes sacras. Además dicta que quienes conserven a su mujer han de perder su oficio y su beneficio, y lo mismo para aquellos que en vez de casarse habían tomado concubina ${ }^{24}$. Hasta el momento y al contrario que en Castilla el papado sólo castigaba a los clérigos casados, lo cual provocó que quienes querían escapar se refugiasen en el concubinato. Conocedora la Iglesia de estos hechos los corta de raíz. Volviendo a Castilla, el Concilio de Valladolid de 1143 recoge con exactitud todas las disposiciones papales, incluidas las últimas, con respecto al matrimonio y al concubinato clerical $^{25}$. Finalmente, el III Concilio lateranense celebrado en 1179 repite lo dictado por su antecesor, confirmando su férrea voluntad $^{26}$. En 1215 el IV Concilio de Letrán da un paso más. En su canon 14 no habla ya de matrimonio o de concubinato de clérigos sino de castidad y continencia. Cualquier falta contra esto será juzgada con severidad ya sea grave o no ${ }^{27}$. La Iglesia está dispuesta a lograr que todos sus miembros de órdenes mayores sean ejemplo de correcta moral sexual. Pero la realidad es que durante toda la Edad Media va a luchar por eliminar el concubinato eclesiástico en toda Europa ${ }^{28}$.

Las disposiciones de los siglos XI y XII son importantes ya que muestran la colocación de las piezas antes del Concilio de Valladolid de 1228, cuando se imponen medidas novedosas. Por un lado sabemos que algunos obispos no sólo conocían las normas, sino que tuvieron algún tipo de intención de aplicarlas. En 1199 Inocencio III responde a una misiva del obispo de Osma ex-

${ }^{21}$ ARRANZ, 21 (Madrid, 2008b): 24.

22 AZNAR, 55/145 (Salamanca, 1998): 506.

23 TEJADA, 1861, Palencia, Concilio de 1129: 257.

${ }^{24}$ AZNAR, 55/145 (Salamanca, 1998): 503-504.

${ }^{25}$ AZNAR, 55/145 (Salamanca, 1998): 507.

${ }^{26}$ SÁNCHEZ HERRERO, 5 (Durango, 2008): 128.

27 GARCÍA, 1981a: 62-63.

${ }^{28}$ Por ejemplo el Concilio de Basilea (1431-1448) sigue mencionando el concubinato eclesiástico: AZNAR, 55/145 (Salamanca, 1998): 504. 
plicándole ciertas dudas que el oxomense le había expuesto sobre cómo actuar contra los clérigos concubinarios ${ }^{29}$. Pero por el otro, estamos ante un clero que tras un siglo de advertencias no está dispuesto a ceder ${ }^{30}$. Aún así, lo más importante es que los contrincantes se conocen, lo cual va a suponer una ventaja para uno de ellos.

Al llegar 1228 las propuestas sobre la eliminación del concubinato eclesiástico llevaban más de un siglo acosando a los clérigos castellanos concubinarios. Ahora la Iglesia castellana va a punir a todos los beneficiarios sea cual sea su categoría ${ }^{31}$. Pero la medida más novedosa y problemática es la excomunión de las concubinas públicas ${ }^{32}$. Esto provoca que sus parejas sean también excomulgadas al no apartarse de ellas ${ }^{33}$. No obstante esta medida fue neutralizada desde el papado. Ya en 1233 encontramos varias bulas que posibilitan a los obispos perdonar las excomuniones en las que habían caído el gran número de clérigos concubinarios ${ }^{34}$. En 1251 Inocencio IV concede no sólo el poder levantar las excomuniones, sino el conmutar las penas establecidas en Valladolid por otras que entendieran más acordes con la situación de cada pecador. El Papa reconoce que las medidas impuestas fueron correctas, pero que trajeron más problemas que soluciones ${ }^{35}$.

La importancia del Concilio vallisoletano no reside tanto en las disposiciones anuladas contra los sacerdotes que vivían en concubinato público, sino sobre todo en otro tipo de medidas que afectan a sus concubinas y a sus hijos. En 1228 la Iglesia castellana contaba con una experiencia de más de cien años de lucha contra el concubinato de clérigos. Por ello conocía muy bien a los afectados, sus deseos, sus miedos y sus preocupaciones, las cuales apenas van a variar en los próximos siglos. Pedro Gómez, obispo de diferentes lugares durante buena parte de la segunda mitad del siglo XIV, relata que durante sus visitas pastorales encontró clérigos que para no abandonar a sus concubinas se excusaban diciendo que habían tenido con ellas muchos hijos o porque llevaban toda la vida con ellos ${ }^{36}$. Consciente de estas preocupaciones, el Concilio de Valladolid va a establecer una serie de medidas que no van contra los sacerdotes directamente sino contra el sustento de sus familias cuando ellos no estén. Son normas nuevas, muy probablemente creadas ex profeso con la esperanza de que, si leyes parecidas a las anteriores no funcionaban, al menos estas sí lo hicieran.

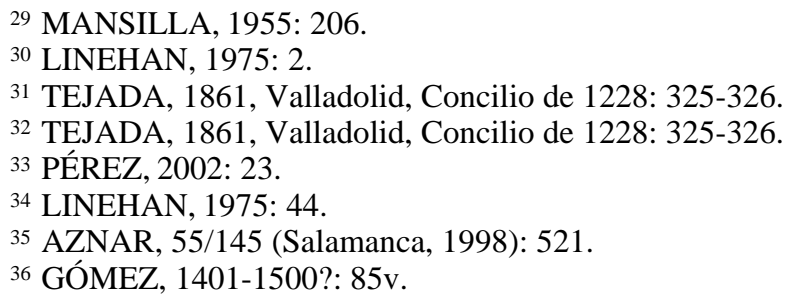




\section{HiJOS DEL PECADO}

Las medidas del Concilio de 1228 de Valladolid que parece enfadaron más al clero concubinario fueron aquellas que afectaban a sus hijos. La Crónica latina de los Reyes de Castilla relata que cuando se establecieron normas contra ellos y los hijos nacidos de estas relaciones, estalló un gran conflicto ${ }^{37}$. Puesto que no era la primera vez que el clero castellano se enfrentaba a castigos por su comportamiento es de suponer que lo que realmente levantó sus iras fueron las disposiciones nuevas contra sus hijos, ya que no se menciona la excomunión a sus concubinas. Además, por primera vez en Castilla una reunión eclesiástica tomaba medidas contra estos vástagos.

\section{La ocultación de los pecados de los clérigos}

El Concilio de Valladolid de 1228 prohíbe a los hijos de los clérigos ser clérigos de corona ${ }^{38}$. De este modo se impide la nefasta imagen que da el que ambos compartan el oficio sacerdotal, así como la perpetuación del fenómeno del concubinato eclesiástico de padres a hijos. Esta prohibición es un duro castigo. Impide a los hijos ponerse al frente de los beneficios que sus padres habían logrado o mejorado. Además los despoja de toda la red de contactos y favores que sus padres habían construido y que los ayudaría a obtener una mejor posición dentro del clero. No obstante el sínodo de Santiago de Compostela de 1229 no recoge esta prohibición y sí una sacada de los cánones del IV Concilio de Letrán, aunque introduce fuertes variantes que la desfiguran. Letrán en vez de prohibir a estos hijos el acceso al oficio de sus padres veta que ejerzan el ministerio en los mismos lugares, evitando así que los lugareños vean a un padre y a un hijo en el mismo puesto inclusive con años de diferencia ${ }^{39}$. No obstante lo que el sínodo de Santiago quiere evitar es que los hijos de los clérigos sucedan directamente a sus padres en las iglesias donde estos ejercieron ${ }^{40}$. No obstante nada dice si entre padre e hijo otro sacerdote ocupa el lugar y los recursos, lo cual supone una clara artimaña. Cabe la posibilidad de encontrar a alguien de confianza al que traspasarlo y que no tarde en renunciar en la persona del hijo ${ }^{41}$. La privación de esos beneficios puede suponer la pobreza, aunque el obispo se compadece de aquellos que son válidos y tienen las órdenes sagradas al proporcionarles otro sostén. La razón de

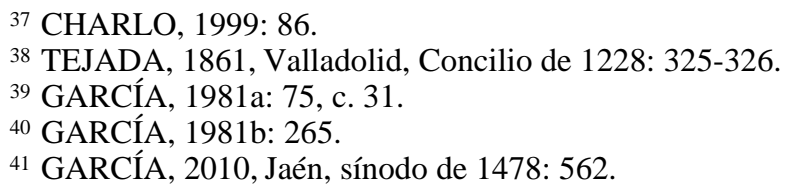


ello es que mendigar no es digno del estado clerical y no parece problemático que estos sacerdotes ejerzan en otros lugares donde sus orígenes familiares no son conocidos. Es una medida sobre todo estética porque intenta ocultar de los ojos de los vecinos el hecho de que el hijo que no debería haber tenido el clérigo ahora es el nuevo beneficiario de los bienes de la iglesia tras la muerte o renuncia del padre. Por ello y para eliminar el ejemplo nefasto que dan se los saca de la comunidad donde son conocidos. Que una medida tan descafeinada se esté promulgando un año después de la reunión vallisoletana es significativo. No olvidemos que este sínodo ignora por completo el resto de disposiciones contra el concubinato de clérigos, probablemente más por pragmatismo que por irreverencia. Vivir en pie de guerra con el clero o tenerlo excomulgado no parece el mejor camino para reformarlo.

Durante el resto del siglo XIII y el XIV esta norma de 1228 parece que fue condenada al olvido. Aunque más bien muta sin perder su esencia. El Concilio de Valladolid de 1322, que representa un giro muy importante en el tipo de penas dirigidas a los clérigos concubinarios públicos ${ }^{42}$, prohíbe que estos oficien los bautizos, desposorios y bodas de sus hijos, nietos u otros descendientes ilegítimos, legítimos o legitimados ${ }^{43}$. Se trata de una medida que frena que estas familias interactúen entre ellas en momentos importantes ante toda la comunidad de creyentes y en la misma iglesia. Al año siguiente en Toledo el espectro de prohibiciones se amplía al pedir que ni la concubina ni los hijos asistan a las misas donde su pareja o padre sean oficiantes ${ }^{44}$. Ya en el siglo $\mathrm{XV}$ a estas prohibiciones se añade la de que los hijos no celebren junto con el padre o no le ayuden durante la misa como monaguillos o recibiendo las ofrendas o limosnas, tareas estas últimas que llevan a cabo las hijas e incluso las mancebas y que también denuncia López de Ayala ${ }^{45}$. En Jaén en 1478 se recuerdan las normas de Santiago en 1229 para que los beneficios no pasen directamente de padres a hijos, normas que se repiten en 1492 y en $1511^{46}$. Y en Burgos, donde se había abordado el problema en 1474, las leyes se endurecen a inicios del $\mathrm{XVI}^{47}$. Es en esta centuria cuando se exige que los clérigos no tengan a sus hijos pequeños en sus casas y que no se hagan acompañar por ellos y sus concubinas por las calles ${ }^{48}$. Son medidas estéticas contra el concu-

42 AZNAR, 55/145 (Salamanca, 1998): 524-525 y 542.

43 TEJADA, 1861, Valladolid, Concilio de 1322: 482-483.

${ }^{44}$ GARCÍA, 2011, Toledo, sínodo de 1323: 540.

45 GARCÍA, 2011, Cuenca, sínodo de 1446: 294-295; 2013, Cartagena, sínodo de 1475: 241-242. LÓPEZ DE AYALA, 1952: verso 227c.

46 GARCÍA, 2010, Jaén, sínodo de 1478: 562, Jaén, sínodo 1492: 587 y Jaén, sínodo 1511: 656.

${ }^{47}$ GARCÍA, 1997, Burgos, sínodo de 1474, compilación de 1503-1511 y 209-210 y Burgos, sínodo de 1511: 287.

${ }^{48}$ GARCÍA, 1984, Oviedo, sínodo de 1553: 490-491; 1990, Plasencia, sínodo de 1534: 455. 
binato ya que piden que los clérigos mantengan una determinada imagen pública en la línea de la máxima «si non caste, tamen caute», que «dejan entrever una mayor preocupación por la imagen pública del pecado que por el verdadero comportamiento de los clérigos» ${ }^{49}$.

\section{Heredar del padre clérigo}

Desde mucho antes de 1228 la documentación muestra la preocupación del clero secular por legar sus bienes a sus hijos. En 1175 Alfonso VIII permite, gracias a la petición de los capitulares y del obispo de Ávila, que todos los clérigos de la diócesis abulense hagan herederos a quienes deseen, lo que implícitamente incluye a sus hijos ${ }^{50}$. Recurrir al rey para estas cuestiones es mucho mejor que hacerlo al Papa como comprueban los clérigos de Palencia. En 1225 Honorio III responde a su misiva comunicándoles que no va a ceder ante su petición de permitir que sus hijos y concubinas hereden sus bienes. Es más, a la vez escribe al obispo de la diócesis pidiéndole encarecidamente que movilice todos los medios posibles para que su voluntad se cumpla ${ }^{51}$. Conocedor de estos deseos, la segunda medida promulgada por el Concilio de Valladolid contra los hijos de los clérigos es impedir que hereden, que sean sostenidos a la muerte de sus padres con el patrimonio amasado gracias a los bienes eclesiásticos. Pero curiosamente la norma solo afecta a los hijos por nacer, lo que parece una medida piadosa hacia los ya nacidos porque no tienen que pagar por los pecados de sus padres ${ }^{52}$. Este estatuto no fue derogado ni tampoco deformado en reuniones posteriores. Entre las normas del Concilio de Valladolid que el sínodo de León de 1267 recoge, se encuentra el impedir a sus hijos heredar. Es más, lo amplía, prohibiendo también las donaciones en vida y extendiéndolo a los hijos ya nacidos ${ }^{53}$. Estas normas no sólo afectan a la economía de los herederos sino a la masculinidad de los clérigos y, por tanto, a la visión que tienen de sí mismos como hombres ${ }^{54}$. El preocuparse por el bienestar de sus vástagos les convertía en buenos padres, verdaderos hombres que proveen de todo lo necesario a sus familias. Pero tal y como ilustra el fuero de Jaca, al dejar como herederos a sus hijos los clérigos descubren su pecado ante el resto de la sociedad ${ }^{55}$. No obstante y al contrario

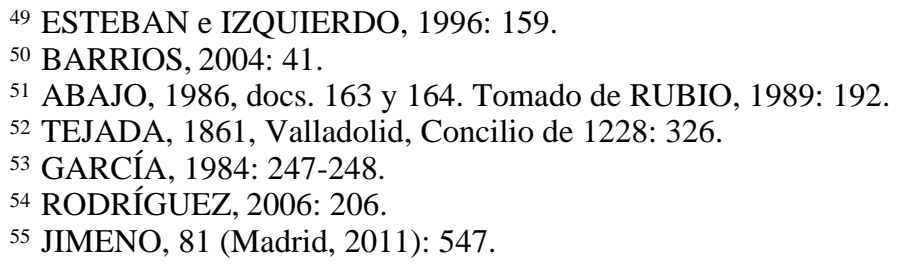


de lo que ocurría en esta villa a finales del siglo XI, en Castilla son muchos los fueros de finales del siglo XII y de la primera mitad del XIII que permiten a los clérigos legar sus bienes a sus hijos de un modo o de otro. De un modo opuesto al fenómeno de los hijos de clérigos que seguían el oficio del padre, en este caso el Concilio tiene que luchar contra diversas leyes forales que conceden a estos vástagos un estatuto muy parecido al de los naturales y, por tanto, con pleno derecho a heredar de sus padres ${ }^{56}$. Incluso el abad de Oña permite que los clérigos del núcleo poblacional que rodea al monasterio dejen como herederos a sus hijos previo pago de una cantidad estipulada ${ }^{57}$. De este modo las leyes territoriales están dando cierta licitud al comportamiento de los clérigos ${ }^{58}$. La prohibición del Concilio, por tanto, tiene el objetivo de acabar con la imagen equivocada que dan los fueros de que los clérigos no tienen por qué guardar castidad.

Pero si las leyes forales anteriores a 1228 contradecían los deseos de renovación de la Iglesia, a partir de esta fecha la Corona va a dar una pátina de licitud al comportamiento sexual de los clérigos. Numerosos reyes van a conceder privilegios mediante los cuales esos hijos pueden heredar sus bienes. Fernando III lo hizo tempranamente en 1238 con los clérigos del término municipal de Guadalajara ${ }^{59}$. Y Alfonso X firma un privilegio parecido para los del obispado de Salamanca en $1262^{60}$. En los años 1270 y 1271 el Rey Sabio da un paso más y directamente legitima a los hijos de los clérigos de los arciprestazgos de Castrojeriz, Roa y Almazán para que puedan heredar como si se trataran de hijos legítimos ${ }^{61}$. Es más, con estos privilegios impide cualquier castigo eclesiástico ya que prohíbe que esos bienes acaben en manos de la Iglesia al prohibir que sean dados o enajenados a esta, a una orden religiosa 0 a una persona de religión ${ }^{62}$. Los motivos de los reyes para conceder estos privilegios no están claros. Puede tratarse de una cuestión poblacional en un momento en el que Castilla necesitaba un impulso demográfico, tal y como afirma Linehan mediante una comparación con lo que sucedía en Portugal ${ }^{63}$. $\mathrm{O}$ una forma de incrementar las fuentes de ingresos a la Corona ${ }^{64}$. Fuese como fuese, sus sucesores en el trono van a confirmar estos privilegios. Por ejemplo el concedido por San Fernando lleva las rúbricas de Sancho IV, Fer-

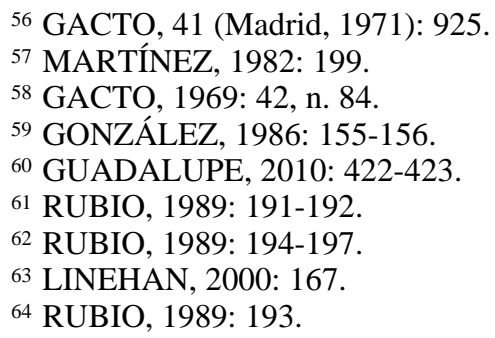


nando IV, Alfonso XI y Juan I65. El último documento creado ex novo que legitime a estos vástagos fue concedido en 1354 por Pedro I a los clérigos de la villa de Ágreda ${ }^{66}$.

¿Cómo se conjugan unas normas eclesiásticas que impiden heredar junto con unas leyes y unos privilegios dados por el rey que lo permiten? Mal. Poco después del sínodo de León de 1267, donde se ratificaron y ampliaron las normas que impedían a los vástagos de los clérigos heredar o recibir donaciones, en esa misma ciudad y en el año 1288 ante el arcediano de Valderas se presentan los siete hijos, la manceba y el yerno de Don Nicolás, clérigo de Castrillo. Entre los bienes que su familiar les dejó en su testamento parece figurar un huerto que el finado, según Fernán García y el testimonio notarial que presenta, le había vendido antes de morir. Parece que Don Nicolás no tuvo ningún impedimento al dejar sus bienes a sus hijos pese a encontrarse a pocos kilómetros de la sede episcopal ${ }^{67}$. Y esto no es una excepción. En 1318 Juan XXII escribe a los obispos de la provincia eclesiástica de Toledo quejándose de sus faltas, entre ellas el dar bienes de la Iglesia a los hijos que han tenido con sus concubinas públicas ${ }^{68}$. En 1326 Xoan, clérigo de coro de la catedral lucense, deja como herederos a sus cinco hijos ${ }^{69}$. En Liébana tres años después Toribio Pérez, clérigo de Santo Toribio, deja en su testamento sus bienes repartidos entre sus seis hijos ${ }^{70}$. Y en marzo de 1338 Alfons Ferrans reconoce haber recibido mil maravedís de mano del arcipreste de Calatañazor en concepto de la dote de la hija de este último ${ }^{71}$. Esto ocurre no mucho tiempo después de que el Concilio de Valladolid de 1322 prohibiera las donaciones de clérigos a sus hijos con motivo de su matrimonio ${ }^{72}$.

Aun así, hay que situar a mediados del siglo XIII el momento en el que la actitud positiva hacia los vástagos de los clérigos se empieza a resquebrajar. El Libro de los Fueros de Castilla no asimila a los hijos de los clérigos con los hijos naturales de los solteros, y por ello les impide participar de cualquier modo en la herencia de su padre, permitiéndoles sólo recibir una cantidad reducida en concepto de limosna ${ }^{73}$. El final de esta tolerancia, al menos en lo legal, hay que situarlo en 1380 en las Cortes de Soria ${ }^{74}$. Juan I, que el 20 de agosto de 1379 había confirmado el privilegio concedido por Fernando III a

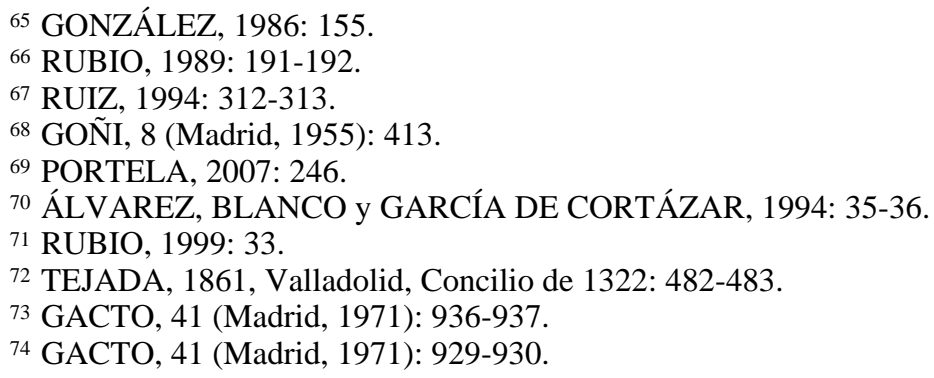


los clérigos de Guadalajara, revoca la validez de estos documentos y prohíbe las herencias, las mandas y las donaciones a estos hijos por parte de sus padres y sus familiares ${ }^{75}$. Y no sólo encontramos este tipo de leyes en las Cortes. En 1463 un Cuaderno de la Hermandad del Señorío de Vizcaya prohíbe que la herencia que reciba un clérigo de sus padres no la pueda transmitir a sus vástagos ${ }^{76}$. La aparición de estas normas hace que los clérigos busquen otras maneras de traspasar su patrimonio a sus hijos. Parece que algunos lo intentaron mediante dotes o donaciones propter nuptias ${ }^{77}$. El sínodo de Córdoba de 1496 prohíbe el fideicomiso, el encontrar una persona de confianza a la que donar o dejar en herencia los bienes para que esta los traspase a los hijos del finado ${ }^{78}$. Pero la documentación muestra que esta trampa ya había sido detectada mucho tiempo antes, a la vez que señala que estas leyes se estaban ejecutando en la primera mitad del XV. De entre los reinados de Enrique III y Juan II data un formulario notarial castellano que contiene un modelo de documento donde se despoja a dos hijos de clérigo de su herencia. Esta había sido puesta en manos de una tercera persona para que más adelante se la cediera a los verdaderos herederos, pero la transacción es descubierta y los bienes pasan a la cámara del rey. Aun así uno de ellos logra que, por ciertos servicios, el rey le haga poseedor de toda la herencia ${ }^{79}$. No obstante todas estas estratagemas parecen ser utilizadas por aquellos clérigos que no han conseguido, por diferentes motivos, que el rey legitime a su prole. En estas cartas de legitimación se indica que ni las leyes de Soria ni ningunas otras pueden impedir a esos hijos heredar de sus padres clérigos ${ }^{80}$. La Corona castellana no dejó de legitimar a los hijos de los clérigos y sus concubinas pese a la presión que ejercía hacia estas parejas a través de las leyes que promulgaba ${ }^{81}$.

\section{COMPAÑERAS DE PECADO}

La bibliografía habla de que el concubinato eclesiástico era visto con normalidad por parte de los laicos ${ }^{82}$. Sin embargo algunos testimonios del siglo XIII parecen indicar que las concubinas de clérigos no eran del todo aceptadas. Tal vez las medidas contra ellas promulgadas en las reuniones religiosas

\footnotetext{
75 REAL ACADEMIA DE LA HISTORIA, 1863, Soria, Cortes de 1380: 303-304.

${ }^{76}$ HIDALGO DE CISNEROS, 1986: 174.

77 GARCÍA, 1997, Palencia, sínodo de 1445, compilación de 1500: 469.

78 GARCÍA, 2013, Córdoba, sínodo de 1496: 413.

${ }^{79}$ GACTO, 41 (Madrid, 1971): 930-931. CUESTA, 1947: XIII y 66.

${ }^{80}$ CUESTA, 1947: 63-65.

${ }^{81}$ Un estudio breve pero conciso sobre la legitimación de bastardos en Castilla a finales del XV se encuentra en CÓRDOBA, 16 (Barcelona, 1986): 611-618.

82 SÁNCHEZ HERRERO, 5 (Durango, 2008): 136-137.
} 
calaron entre sus vecinos y conocidos. Lo cierto es que avanzada la segunda mitad de ese siglo su presencia levanta críticas, justo por las mismas fechas cuando la tolerancia hacia sus hijos se empieza a resquebrajar.

\section{Mujeres peligrosas, mujeres degradadas}

Cuando en 1059 se prohíbe el matrimonio a los presbíteros y en 1123 se declaran nulas estas uniones, las parejas de estos hombres pasan a ser concubinas y como tales son denominadas en el resto de reuniones eclesiásticas. Tal vez la diferencia práctica entre un matrimonio y un concubinato podía no ser mucha o ser casi inexistente en el siglo XI y la primera mitad del XII, pero en el ámbito religioso la diferencia sí es palpable. Se pasa de estar en la relación aceptada por la Iglesia a otra que no lo es. Para una persona religiosa la diferencia debía ser insalvable. Pero si pasar de mujeres a concubinas tal vez no resultaba traumático, las medidas tomadas en el Concilio de Palencia de 1129 no podían dejarlas indiferentes al ser expulsadas de las casas donde vivían con sus compañeros por estos o por las justicias, delante de toda la comunidad. La reunión palentina inaugura una serie de castigos directos hacia estas mujeres que afectan a su posición en la sociedad, influyendo en el cómo debían ser vistas y también en el cómo se debían ver a sí mismas.

El Concilio de Valladolid de 1228 impone castigos religiosos a las concubinas de clérigos. Son excomulgadas y por tanto apartadas de la comunidad de creyentes. Si mueren sin reconciliarse, al contrario de lo que le ocurriría a otro excomulgado, el Concilio exige que no sean enterradas en un lugar decente. Han de ser sepultadas en el mismo espacio donde se entierra a los animales $^{83}$. Las palabras son muy claras y representan un castigo social más allá de la muerte: las concubinas de clérigos no pertenecen a la comunidad humana. Simbólicamente esto las coloca en vida al mismo nivel de trato y valor social que los animales. En 1267 un sínodo de León prohíbe que sean enterradas en presencia de un sacerdote al suspender de oficio y beneficio a los clérigos que se presten a ello o incluso a los que simplemente asistan. Además amenaza con la excomunión a los legos que vayan al entierro ${ }^{84}$. La negación no ya de un sepelio cristiano sino de un simple acompañamiento, indica el deseo de degradar a estas mujeres tanto en vida como tras su muerte. Pero esta constitución tuvo que ser derogada. El sínodo de 1303 cuenta que ha sido informado de que muchos son los clérigos y legos que desconocen los peligros de enterrar a una concubina, así que viven suspensos o excomulgados sin

83 TEJADA, 1861, Valladolid, Concilio de 1228: 325-326.

${ }^{84}$ TEJADA, 1861, León, Concilio de 1267: 396. 
saberlo $^{85}$. Tal y como ocurrió con las excomuniones a los clérigos en 1228 levantadas por Inocencio IV, se reconoce que la medida es correcta y se espera volver a ponerla en marcha en un futuro no muy lejano, pero se ha de suspender porque implica más problemas que soluciones. Ese hipotético futuro es el que se vislumbra en la diócesis de Cuenca en 1402. El sínodo de aquel año estipula la suspensión para el clérigo que entierre a una concubina de clérigo, aunque con bastantes diferencias con la norma leonesa de 1267. Será suspendido sólo si el entierro es dentro del cementerio, si es plenamente consciente de que ella era concubina de clérigo y si lo fue hasta sus últimos días, pues no habrá castigo si se apartó de su mala vida dos meses antes o más de su muerte ${ }^{86}$. De los asistentes al sepelio, legos o clérigos, no se dice nada. La norma, pese a su dureza, está muy lejos de lo dictado en Valladolid en 1228 y en León en 1267.

El intentar negar un entierro cristiano y humano a las concubinas de clérigos no fue la única ley que sínodos y concilios no consiguieron hacer efectiva contra estas mujeres. Al igual que sucedía con las herencias, donaciones y otros traspasos de bienes a los hijos, que las concubinas disfrutasen de ellas suponía también un mal ejemplo, así como una forma de dar normalidad a estas relaciones de pareja. Las barraganas de los legos tenían derecho a heredar de sus compañeros ${ }^{87}$. Un derecho que parece también tenían, o habían tomado las compañeras de los clérigos. En 1175 Alfonso VIII permite a los clérigos de Ávila que hagan herederos a quienes deseen, y eso incluye a sus concubinas. Pero el sínodo de León de 1267 prohíbe que sean beneficiarias de cualquier traspaso de bienes durante la vida o tras la muerte de sus clérigos ${ }^{88}$. Esta norma empeora las posibilidades de subsistencia de las concubinas y las de sus hijos. Antes de 1228 es probable que tras «enviudar», al igual que las barraganas de legos, no sólo heredasen los bienes de sus parejas sino que también pudiesen administrar los bienes de sus hijos menores de edad ${ }^{89}$. Con estas normas, sobre todo con la leonesa de 1267, el futuro de las concubinas tras la muerte de sus compañeros debería empezar a oscurecerse. Pero tal y como ocurría con la prohibición de que los hijos de los clérigos heredasen de sus padres, encontramos multitud de documentos que demuestran su incumplimiento. En 1288 la concubina de Don Nicolás heredó sin ningún problema junto con la extensa prole de este, pese a encontrarse cerca de León y tener que recurrir al arcediano ${ }^{90}$. En Salamanca en 1296 María Pascual, «criada»

85 GARCÍA, 1984, León, sínodo de 1303: 269.

${ }^{86}$ GARCÍA, 2011, Cuenca, sínodo de 1402: 104.

87 GACTO, 1969: 48.

88 GARCÍA, 1984: 247-248.

89 GACTO, 1969: 48-49.

${ }^{90}$ RUIZ, 1994: 312-313. 
del difunto canónigo Rodrigo, dona a la catedral una casa para la salvación de las almas de ambos y que poseía gracias al clérigo ${ }^{91}$. En 1326 Xoan, clérigo de coro de la catedral lucense, deja todos sus bienes a la que con toda probabilidad sea su manceba y a sus cinco hijos ${ }^{92}$. En 1329 en Liébana sabemos que el clérigo de Santo Toribio reparte sus posesiones entre una de las dos o tres mancebas que tuvo y sus seis hijos ${ }^{93}$.

Mientras que las normas eclesiásticas dejaban clara su opinión sobre las concubinas de clérigos, durante el XIII existe otro frente de incomprensión hacia estas mujeres. En 1290 las ordenanzas de Sevilla obligan a las concubinas públicas de clérigos a sentarse no entre las mujeres casadas, sino detrás de estas y junto con las barraganas de casados. Muy probablemente acompañándolas se encontraban las prostitutas ya que tenían prohibido sentarse con las casadas durante las celebraciones religiosas ${ }^{94}$. La casada en la Edad Media castellana es la mujer que ha logrado los objetivos marcados por la sociedad para su género. Las mancebas de clérigos viven como ellas, tienen hijos, cuidan de sus parejas y guardan la casa, pero pese a todas las similitudes las ordenanzas las indican de un modo muy gráfico que aunque se sientan como casadas, no lo son. Son mujeres de segunda y por tanto su posición dentro del templo ha de ser también secundario, alejado del altar. Un testimonio muy parecido lo encontramos en el Poema de Elena y María, escrito en tierras leonesas y fechado por Menéndez Pidal en 1280 y por Franchini en los años 20 o 30 del XIII ${ }^{95}$. Elena recuerda a su hermana que si va a misa se tendrá que sentar detrás de todas las mujeres por ser concubina de un clérigo ${ }^{96}$. Parece que ni Sevilla ni Murcia fueron los primeros lugares en imponer un orden jerárquico de las mujeres en misa y que no aparece en ningún sínodo o concilio. Mucho menos sutil va a ser el sínodo de Toledo de 1342. Castiga a todas las concubinas, ya sean de clérigos, de solteros o de casados, a ser despojadas automáticamente de sus ropas cada vez que crucen la puerta de una iglesia durante los oficios religiosos. Se trata de una pena infamante, muy practicada tanto a malhechores como a prostitutas ${ }^{97}$. La identificación de quién es quién para la Iglesia toledana es clara. Al castigar a las concubinas del mismo modo que a las prostitutas pone a ambas instituciones a la misma altura y hace que quien contemple el castigo crea que está ante mujeres que se prostituyen, dañando así su imagen pública.

91 GUADALUPE, 2010: 635-636.

92 PORTELA, 2007: 246.

${ }^{93}$ ÁLVAREZ, BLANCO y GARCÍA DE CORTÁZAR, 1994: 35-36.

94 GONZÁLEZ ARCE, 2003: 196.

${ }^{95}$ FRANCHINI, 2001: 103-104.

${ }^{96}$ FRANCHINI, 2001, versos 215-218.

97 SÁNCHEZ HERRERO, 1978: 159-160. 
Estas medidas para desprestigiar a las concubinas de clérigos van a ser también tomadas por la Corona. Las Cortes de Valladolid de 1351 siguen la senda de las ordenanzas de Sevilla. Se dice que su ufanía y soberbia, en parte provocada por sus costosos ropajes, atenta contra la reverencia y el honor de las mujeres honradas y las casadas, es decir, aquellas que viven su sexualidad conforme a las reglas sociales. Afirman que las concubinas han de respetar a estas mujeres, lo cual significa que están por debajo de ellas, una posición de inferioridad que parece no estén dispuestas a aceptar y provoca peleas ${ }^{98}$. Por ello van a ser marcadas al ser obligadas a llevar un prendedor de color bermejo en las tocas. Esta señal vergonzosa que va más allá del umbral de los templos, las impide confundirse con el resto de mujeres y las identifica socialmente, siendo ese el objetivo de la ley ${ }^{99}$. Las Cortes de Soria, las mismas que derogaron todos los privilegios reales para que los hijos de los clérigos heredasen, van a recordar esta ley haciendo hincapié en que las mancebas de clérigos han de ser diferenciadas de las casadas ${ }^{100}$. El objetivo de ambas disposiciones de cortes es el mismo: evitar que las mujeres honradas quieran convertirse en barraganas de clérigos.

Las Cortes de 1351 no sólo imponen el prendedor bermejo a las concubinas clericales, sino que les prohíben llevar ropajes $\operatorname{caros}^{101}$. Estos son un signo de riqueza y por tanto de los privilegios materiales de los que disfrutan. Un volumen de bienes que posiblemente en esas fechas gozasen más que nunca, ya que el terror que sobrevino con la peste negra provocó un gran aumento del número de donaciones a las iglesias por parte de los fieles ${ }^{102}$. Las Cortes reunidas en Valladolid ven peligro en esta ostentación no sólo porque crea estatus sino porque puede funcionar como un aliciente para que las mujeres honradas abandonen el camino del matrimonio ${ }^{103}$. Despojadas de sus ricas vestiduras y portando una señal que las distinguía, ya no pueden parecerse a las mujeres más respetadas por la sociedad por mucho que vivan en la opulencia. Esta referencia a las riquezas de las que disfrutan gracias a sus compañeros, y en especial sus vestidos, aparece en otros documentos. Ya en la primera mitad del siglo XIII Elena critica abiertamente a María porque el origen de sus ropas, alimentos y otros bienes de los que disfruta está en la Iglesia y en las limosnas de los parroquianos ${ }^{104}$. Un siglo y medio después el Rimado de palacio menciona que suelen ser estas mujeres las mejor vestidas y arre-

\footnotetext{
98 REAL ACADEMIA DE LA HISTORIA, 1863, Valladolid, Cortes de 1351: 14-15.

99 REAL ACADEMIA DE LA HISTORIA, 1863, Valladolid, Cortes de 1351: 14-15.

100 REAL ACADEMIA DE LA HISTORIA, 1863, Soria, Cortes de 1380: 304-305.

101 REAL ACADEMIA DE LA HISTORIA, 1863, Valladolid, Cortes de 1351: 14-15.

102 VACA, 2 (Salamanca, 1984): 102.

103 REAL ACADEMIA DE LA HISTORIA, 1863, Valladolid, Cortes de 1351: 14-15.

104 FRANCHINI, 2001, versos 205-210.
} 
gladas $^{105}$. Fuera del ámbito literario tenemos la denuncia a un agustino por un sermón que dio entre 1370 y 1400 en Alcalá de Guadaíra. En él dijo a los labradores que las ofrendas y limosnas que realizaban a la Iglesia acababan en manos de las mancebas de los clérigos, las cuales se paseaban por la calle con vestidos caros y con la bolsa repleta ${ }^{106}$. Esta muestra de poder económico no sólo ocurría mientras vivían con sus compañeros, sino también cuando estos morían al administrar los bienes que sus hijos habían heredado. Cuando Juan I anula los privilegios que permiten a los hijos de los clérigos heredar, se dice que deben ser revocados porque fomentan que las vírgenes y las viudas se emparejen con hombres de Iglesia ${ }^{107}$.

Convertidas en mujeres de segunda, señaladas y al cargo de unos hijos con dificultades para heredar de sus padres, en 1380 ser concubina de clérigo no es tan atractivo como lo podía haber sido antes. No obstante van a seguir disfrutando de los bienes de sus parejas ya que las prohibiciones eclesiásticas a que las nombren herederas o les donen diferentes riquezas son ignoradas. En junio de 1403 cuando el clérigo Diego Negro muere, sus dos hermanas acuerdan con María Ferrández cómo repartirse los bienes del finado ${ }^{108}$. Durante el resto del siglo $\mathrm{XV}$ las herencias y donaciones de bienes a las concubinas se siguen produciendo ya que encontramos su prohibición en sínodos como el de Palencia en 1445 o Salamanca en $1451^{109}$. Pero pese a estas riquezas, las Cortes de 1387 de Briviesca van a degradarlas socialmente de forma definitiva al convertirlas en criminales. Tanto las Cortes de Valladolid de 1351 como las de Soria de 1380 se habían contentado con señalarlas y hacerlas inferiores, buscando que las mujeres no viesen la mancebía de clérigos como una opción más entre las que una mujer honrada podía elegir. Tal vez estas disposiciones no tuvieron el éxito previsto puesto que las Cortes de 1387 pasan de señalar a perseguir, haciendo que las concubinas de clérigos transiten de representar una opción alternativa de vida femenina a engrosar las filas de los fuera de la ley ${ }^{110}$. Cada vez que sean sorprendidas tendrán que pagar un marco de plata. La ley favorece la denuncia y persecución al permitir que cualquier persona las pueda denunciar y que parte de la multa vaya a las manos del denunciante. No obstante la ley falla en un punto esencial, pues ni se determinan castigos para las que reincidan ni se las pide que abandonen su vida, confiándolo todo al efecto disuasorio de la multa económica. Tras esta fecha la discreción se

105 LÓPEZ DE AYALA, 1952, verso 227b.

106 GONZÁLEZ JIMÉNEZ, 2011: 94.

107 REAL ACADEMIA DE LA HISTORIA, 1863, Soria, Cortes de 1380: 303-304.

${ }^{108}$ FERNÁNDEZ SUÁREZ, 1993: 142-143.

109 GARCÍA, 1997, Palencia, sínodo de 1445, compilación de 1500: 469; 1987, Salamanca, sínodo de 1451: 310-311.

110 REAL ACADEMIA DE LA HISTORIA, 1863, Briviesca, Cortes de 1387: 369-370. 
impone si no quieren ser desangradas económicamente, lo cual significa el último golpe a ese orgullo que María, la hermana de Elena, todavía y pese a las incipientes dificultades mostraba abiertamente a mediados del siglo XIII.

\section{El fin del orgullo de María: la criminalización de las concubinas de cléri- gos}

Pese al gran cambio que representa para las concubinas de clérigos la ley promulgada en Briviesca en 1387, hay testimonios que dicen que no fue formulada para hacerla cumplir. En 1396 una carta de Enrique III dirigida a la clerecía sevillana afirma que ha sido informado de que su padre no creó esa ley con la intención de que se ejecutase, sino para atemorizar a las concubinas y que se separasen de los clérigos ${ }^{111}$. Y esta misma carta fue mostrada casi un siglo después a los Reyes Católicos, ya que recuerdan con exactitud las mismas palabras ${ }^{112}$.

Contra lo deseado por Juan I la ley no se convirtió en letra mojada. Muestra de ello es que su sucesor Juan II en 1433 la incluyó en unas ordenanzas dirigidas a aclarar los cobros de salarios y las actividades propias de determinados oficios públicos ${ }^{113}$. Pero sobre todo por varios conflictos surgidos por su mala aplicación por parte de las justicias concejiles. Estos son la mejor muestra de que desde finales del siglo XIV y hasta 1478 las leyes fueron puestas en marcha, y por tanto, las concubinas de clérigos perseguidas y criminalizadas.

Tres son las situaciones que van a enfrentar a justicias y concejos contra clérigos y concubinas al hacer cumplir las leyes de Briviesca. La primera y más abundante es que las justicias pasan directamente al arresto y a la pena, tal y como ocurre en 1396 en Sevilla ${ }^{114}$. Las Cortes de Briviesca dictan que las mancebas deben ser públicas, lo que conlleva que se debe comprobar previamente al arresto que no se trata de una familiar o de personal doméstico sin más ${ }^{115}$. La forma de comprobarlo es recordada en una carta de Fernando de Antequera a las justicias de la villa de Cuéllar en 1414116. Previo al arresto y al cobro de la multa, a las presuntas concubinas de clérigo se las ha de em-

\footnotetext{
111 ORTIZ DE ZÚÑIGA, 1677: 257.

112 AGS, Registro General del Sello, 1478-09-03, f. 127.

113 ABELLÁN, 1984: 444.

114 ORTIZ DE ZÚÑIGA, 1677: 257.

115 REAL ACADEMIA DE LA HISTORIA, 1863, Briviesca, Cortes de 1387: 369-370.

116 VELASCO, HERRERO, PECHARROMÁN y MONTALVILLO, 2010, doc. 266.

Agradezco a mi compañero el Dr. Muñoz Gómez el haberme comunicado la existencia de este documento así como su envío.
} 
plazar a juicio donde se puedan defender y condenarlas si son encontradas culpables. Las justicias cuellaranas las habían apresado sin un juicio previo y no las habían dejado salir hasta que pagaron, mientras que las que no pudieron fueron desterradas o azotadas por las calles de la villa. De exactamente lo mismo se queja en 1410 la clerecía de Murcia, pues el alguacil mayor ha apresado así a algunas de sus criadas. Según ellos, desde que San Vicente Ferrer pasó por la ciudad ese mismo año ya no viven amancebados ${ }^{117}$. Las justicias parecen actuar bajo la máxima de que si una mujer vive con un clérigo, mantiene relaciones sexuales con él. Los clérigos murcianos excusan la presencia de féminas en sus casas alegando que las necesitan para que se encarguen de las tareas domésticas ${ }^{118}$. Pero las justicias parecen no creerlos. El mismo grado de incredulidad encontramos en el obispo de Sevilla Pedro Gómez, expresado por unas palabras que pone en boca de San Jerónimo: «están con muger e non conosçen muger, mayor miraglo es que rresçuçitan un muerto» ${ }^{119}$.

La falta de un juicio previo al arresto de las supuestas concubinas es denunciado en 1446 por el sínodo de Cuenca, y a ello hay que añadir el que las justicias entran en las casas de los clérigos sin permiso para llevarse a las mujeres que allí encuentran. Para defenderse de este abuso en el futuro se excomulgará a quienes tales atropellos cometan ${ }^{120}$. Ese mismo año en Jaén las justicias se llevan a todas las mujeres que encuentran en las casas de los clérigos, incluyendo familiares con las que el derecho canónico los deja vivir. El documento remitido al príncipe Enrique IV por el deán y Cabildo de la Iglesia de Jaén y los canónigos de otras poblaciones, describe algunos de los modus operandi de las justicias jienenses. Cuando aparecen en las casas de los clérigos por la noche se hacen pasar por personas que buscan a un cura para que administre algún sacramento de urgencia a un familiar; de este modo les abren las puertas y así pueden entrar para ver con quiénes viven. En otras ocasiones entran por los tejados y por las paredes ${ }^{121}$.

Un tercer conflicto es el hecho de que las justicias no solo apresan y exigen indebidamente el pago del marco de plata a las supuestas mancebas que viven con los clérigos, sino también a mujeres que en el pasado fueron sus parejas. Pese a que las leyes piden actuar solo contra las mancebas actuales, las justicias de Jaén no distinguen ${ }^{122}$. Y menos aún las de Cuéllar, donde son las antiguas concubinas de clérigos las que piden justicia a su señor ${ }^{123}$.

${ }^{117}$ RUBIO GARCÍA, 1991: 60-61.
${ }^{118}$ RUBIO GARCÍA, 1991: 190-191.
${ }^{119}$ GÓMEZ, 1401-1500?: 64r-v.
${ }^{120}$ GARCÍA, 2011, Cuenca, sínodo de 1446: 318.
${ }^{121}$ AGS, Registro General del Sello, 1478-01-15, f. 60.
${ }^{122}$ AGS, Registro General del Sello, 1478-01-15, f. 60.
${ }^{123}$ VELASCO, HERRERO, PECHARROMÁN y MONTALVILLO, 2010, doc. 266. 
Más que la moral o su sentido del deber, lo que parece que espoleó a las autoridades civiles a hacer cumplir las leyes fue el cobro del marco de plata, el cual debía dar pingües beneficios ya que se arrendaba a particulares ${ }^{124}$. La primera referencia a estos arrendamientos es de 1396, cuando el clero sevillano se queja al monarca de que los encargados de cobrarlo están inculpando a mujeres inocentes ${ }^{125}$. En 1414 en Cuéllar las justicias tienen también un claro interés económico: no dejan salir de la cárcel a las mujeres acusadas a no ser que se dejen extorsionar y paguen ${ }^{126}$. Lo mismo denuncian los clérigos de Jaén en $1446^{127}$. Es posible que quien se podía permitir pagar el marco de plata o cualquier otro chantaje más de una vez, lo convirtiera en una especie de impuesto con el cual comprar a las autoridades, más interesadas en su bolsillo que en hacer cumplir las normas. No hemos de olvidar que las Cortes de Briviesca no contemplaron penas para las reincidentes.

Pero cuando las justicias aparecen ante la puerta no es sólo el pago de una multa lo que está en juego, sino también el honor. Las quejas de los clérigos se producen porque la forma de hacer cumplir la ley hace que pierdan su buen nombre. El hecho de que las justicias entren sin su permiso en sus casas, atenta contra sus privilegios y posición, así como el querer llevarse prendas como pago por el marco de plata e incluso a ellos mismos ${ }^{128}$. Pero el que de su hogar salga una mujer arrestada es un mensaje muy claro para el resto de la comunidad aunque la acusación sea falsa, pues la imagen social ya está dañada. De este modo son injuriados y difamados ${ }^{129}$. Es tal el aprecio de algunos por su honor y/o la clarividencia de lo que va a pasar, que siendo inocentes no dudan en ceder ante el chantaje y pagar a las autoridades para que se vayan ${ }^{130}$. Y como acto que deshonra, no es raro que encontremos las acusaciones de concubinato imbricadas en otros conflictos. En el año 1402 el cabildo de la iglesia de Valencia de Don Juan escribe al rey quejándose de que Martín Vázquez de Acuña, señor del lugar y en abierta guerra contra ellos, ha vuelto a atacarles. Esta vez no ha ocupado sus propiedades o ha desnudado a un clérigo, sino que ha arrestado a sus sirvientas acusándolas de ser sus mancebas, actos considerados todos ellos como agravios ${ }^{131}$. El hecho de que digan que por ser acusados de vivir en pareja van a ser difamados o que se quejen de

124 CÓRDOBA, 16 (Barcelona, 1986): 608.

125 ORTIZ DE ZÚÑIGA, 1677: 257.

126 VELASCO, HERRERO, PECHARROMÁN y MONTALVILLO, 2010, doc. 266.

127 AGS, Registro General del Sello, 1478-01-15, f. 60.

128 AGS, Registro General del Sello, 1478-01-15, f. 60. AGS, Registro General del Sello, 1478-09-03, f. 127.

${ }^{129}$ GARCÍA, 2011, Cuenca, sínodo de 1446: 318. AGS, Registro General del Sello, 147809-03, f. 127.

${ }^{130}$ AGS, Registro General del Sello, 1478-09-03, f. 127.

131 DOMÍNGUEZ, 2001: 294-297. 
esas falsas acusaciones, demuestra que en el siglo XV el concubinato de clérigos podía ser normal, pero no por ello estaba socialmente bien visto.

Cuando los conflictos por las concubinas de clérigos surgen, la Corona y los señores territoriales tienen dos maneras de solucionarlos. La primera es recordar a las justicias cómo han de aplicar las leyes de Briviesca, derogar todas las multas y los castigos impuestos injustamente y sancionarlas si vuelven a actuar de este modo ${ }^{132}$. La segunda es suspender o dificultar la ejecución de las leyes mediante algún tipo de privilegio. Es lo que parece ocurrir en Paredes de Nava en un momento indeterminado entre 1387 y 1478, cuando los clérigos del lugar presentaron ante el concejo una carta firmada por el rey para «que les non echasen fuera las barraganas» ${ }^{133}$. Las dificultades interpretativas sobre este texto son muchas pero la intervención del rey en favor de los clérigos concubinarios es clara. No parece una hipótesis descabellada que la Corona volviese a tolerar el concubinato de clérigos como lo había hecho antes. El problema es que se desconocen más documentos de este tipo. Solo tenemos algunos indicios de la posible suspensión de las leyes de Briviesca en la Sevilla de $1396^{134}$. Cuando los clérigos se quejaron a Enrique III de que las personas a las que había encomendado el cobro del marco de plata estaban cometiendo algunos abusos, el rey fue informado de que su padre nunca había tenido intención de que la ley se ejecutase. Hasta aquí el resumen del documento que hace Ortiz de Zúñiga no ofrece dudas. El problema surge al interpretar lo que quiere decir con «lo mandó cessar». Si el rey fue informado de que su padre nunca tuvo la intención de que la ley se cumpliese, no sería extraño que lo que mandara cesar fuera la actividad de los recaudadores, lo que desmontaba las condenas efectivas a las concubinas de clérigos. Este documento de 1396 vuelve a ser mencionado en 1478. En la misma carta en la que los Reyes Católicos comunican a los miembros de la Iglesia de Toledo la suspensión de las leyes de Briviesca, recuerdan cuál fue la intención de Juan I. Si los Reyes Católicos fundamentan parte de su decisión de derogar las leyes en la voluntad de su antecesor, no sería de extrañar que Enrique III se apoyase en las mismas palabras para llegar a un mismo resultado.

En 1478 los Reyes Católicos reconocen que las normas dictadas en Briviesca no funcionan y no se espera que funcionen ${ }^{135}$. Pero el fracaso no fue tan estrepitoso como afirman. En numerosos lugares las concubinas eran castigadas aunque las deficiencias de una ley que no pena a las reincidentes, las

132 VELASCO, HERRERO, PECHARROMÁN y MONTALVILLO, 2010, doc. 266. AGS, Registro General del Sello, 1478-01-15, f. 60.

133 MARTÍN CEA, 1991: 428. Fechas aportadas amablemente por el Dr. Martín Cea al que le agradezco desde aquí su ayuda.

134 ORTIZ DE ZÚÑIGA, 1677: 257.

135 AGS, Registro General del Sello, 1478-09-03, f. 127. 
dudas sobre sus objetivos, la sospechosa voluntariedad de las justicias y tal vez la concesión de privilegios reales eximiéndolas de cualquier castigo pudieron enmascarar la realidad más que cambiarla. Durante los dos años que las leyes estuvieron derogadas muchas fueron las parejas que decidieron no seguir ocultándose. Las Cortes de 1480 afirman que «muchos clérigos han tomado osadía de tener las mancebas públicamente e ellas de se publicar por sus mugeres», lo cual lleva a poner en funcionamiento nuevas leyes mejoradas contra el concubinato de clérigos ${ }^{136}$. Este fue el último canto de cisne del orgullo de las concubinas públicas de clérigos y cabe preguntarse cómo fue posible. Las Cortes de 1480 hacen expresa referencia a que al contrario de lo que ocurría con las Leyes de Briviesca, las medidas impuestas por el Concilio de Sevilla de 1478 que debían reemplazar a las briviescanas no levantaron temor alguno ${ }^{137}$. Y en cierto modo esto no es de extrañar ya que las medidas del Concilio sevillano no ofrecen ninguna novedad para lograr el éxito que desde el siglo XII la Iglesia castellana no había logrado ${ }^{138}$. Pero el talón de Aquiles de estas relaciones eran sus miembros adultos y responsables no privilegiados, ellas, a las que la justicia civil sí podía castigar. Si los clérigos no quieren dejar de vivir en concubinato público lo que hay que impedir es que encuentren mujeres dispuestas a ser públicamente sus parejas, algo que la ley de Briviesca había conseguido por lo que sabemos ocurrió entre 1478 y 1480. Y exactamente ese es otra vez el objetivo de las Cortes de Toledo de 1480. Ahora, cuando sean sorprendidas por segunda vez, tendrán que pagar un marco de plata, pero también serán desterradas del lugar por un año. Y si son descubiertas una tercera serán castigadas económicamente y recibirán cien azotes ${ }^{139}$. La voluntad de los reyes ya no es inspirar temor con esta norma sino hacerla cumplir, de ahí que los castigos aumenten junto con la resistencia de las concubinas. Tras 1480 la persecución y la clandestinidad vuelven ${ }^{140}$.

\section{EPÍLOGo}

Tras más de un siglo intentando que los clérigos concubinarios fueran castos, en 1228 la Iglesia castellana decidió golpear a estos donde más les dolía: en sus hijos y parejas. No mucho tiempo después empezó a nacer en la sociedad un sentimiento de molestia hacia las barraganas de clérigos y sus hijos. Pero su status quo se mantuvo gracias a que los esfuerzos de la Iglesia fueron

\footnotetext{
${ }^{136}$ REAL ACADEMIA DE LA HISTORIA, 1882, Toledo, Cortes de 1480: 143-145.

137 REAL ACADEMIA DE LA HISTORIA, 1882, Toledo, Cortes de 1480: 143-145.

138 FITA, 1893: 233, c. VII.

139 REAL ACADEMIA DE LA HISTORIA, 1882, Toledo, Cortes de 1480: 143-145.

${ }^{140}$ CÓRDOBA, 16 (Barcelona, 1986): 609-610.
} 
neutralizados por la negligencia y la dejadez de sus autoridades, así como por los reyes castellanos que protegieron a estas familias hasta finales del XIV. Con Juan I los hijos de clérigos fueron desheredados y sus barraganas convertidas en criminales y perseguidas. No obstante, algunos clérigos consiguieron eludir las trabas y sus hijos heredaron sus bienes, aunque no hay que olvidar que los reyes nunca dejaron de legitimar a estos «hijos del pecado». Y en algunos lugares consiguieron que las leyes de Cortes no se cumplieran por mandato real, impidiendo que las barraganas fueran multadas. Pero a nivel social la barraganía de clérigos ya no estaba bien vista. No obstante, sus hijos, desheredados por la Corona, podían ser legitimados por esta.

Entre los siglos XI al XV los hijos y las barraganas de clérigos van a ir de la luz a la oscuridad, de una vida familiar normal a la clandestinidad. Su presencia impedía que la moral sexual de la Iglesia fuera respetada. Pero la historia de la barraganía de clérigos no es una historia fácil; en ella se entremezclan no solo los objetivos de la Iglesia y los clérigos, sino también sus mujeres, sus hijos, la indescifrable voluntad de los reyes y una sociedad que cada día criticaba más a estas familias. Aún menos es una historia homogénea en el espacio si nos fijamos en lo que ocurre con las herencias antes de 1380 y la persecución de barraganas después de 1387 . Y tampoco es una historia lineal si se recuerda lo ocurrido entre 1478 y 1480. La luz y la oscuridad se alternan y hasta conviven. Pero al final estas familias se instalaron en esta última para siempre, un pobre resultado para la Iglesia tras más de 400 años de lucha.

\section{BIBLIOGRAFÍA CITADA Y FUENTES EDITADAS}

Abajo Martín, Teresa, Documentación de la Catedral de Palencia (1035-1247), Palencia, Ediciones J. M. Garrido Garrido, 1986.

Abellán Pérez, Juan (ed.), Colección de documentos para la Historia del reino de Murcia. XVI, Documentos de Juan II, Murcia, Academia Alfonso X el Sabio, 1984.

Álvarez Llopis, Elisa, Blanco Campos, Emma y García de Cortázar y Ruiz de Aguirre, José Ángel, Colección diplomática de Santo Toribio de Liébana (1300-1515), Santander, Fundación Marcelino Botín, 1994.

Álvarez Palenzuela, Vicente Ángel, Colección documental del archivo de la Catedral de León. Actas Capitulares II, León, Centro de Estudios e Investigación San Isidoro, 2007.

Arranz Guzmán, Ana, «Amores desordenados y otros pecadillos del clero», en Ana Isabel Carrasco Manchado y María del Pilar Rábade Obradó (eds.), Pecar en la Edad Media, Madrid, Silex, 2008a: 227-262.

Arranz Guzmán, Ana, «Celibato eclesiástico, barraganas y contestación social en la Castilla bajomedieval», Espacio, tiempo y forma. Serie III, Historia Medieval, 21 (Madrid, 2008b): 13-39. 
Aznar Gil, Federico R., «La penalización de los clérigos concubinarios en la Península Ibérica (siglos XIII-XVI)», Revista española de derecho canónico, 55/145 (Salamanca, 1998): 503-546.

Barrios García, Ángel, Documentos de la Catedral de Ávila (siglos XII-XIII), Ávila, Institución Gran Duque de Alba y Obra Cultural de la Caja de Ahorros de Ávila, 2004.

Brundage, James A., La ley, el sexo y la sociedad en la Europa medieval, México D.F., Fondo de Cultura Económica, 2000.

Charlo Brea, Luis (ed.), Crónica latina de los reyes de Castilla, Madrid, Akal, 1999.

Córdoba de la Llave, Ricardo, «Las relaciones extraconyugales en la sociedad castellana bajomedieval», Anuario de estudios medievales, 16 (Barcelona, 1986): 571-620.

Cuesta Gutiérrez, Luisa, Formulario notarial castellano del siglo XV, Madrid, Publicaciones del Instituto Nacional de Estudios Jurídicos, 1947.

Domínguez Sánchez, Santiago, Colección documental de los bachilleres de San Marcelo y de las parroquias de Nuestra Señora del Mercado, Valencia de Don Juan y Valderas, León, Centro de Estudios e Investigación San Isidoro, 2001.

Esteban Recio, Asunción e Izquierdo García, María José, «Pecado y marginación: mujeres públicas en Valladolid y Palencia durante los siglos XV y XVI», en Juan Antonio Bonachía Hernando (ed.), La ciudad medieval: aspectos de la vida urbana en la Castilla bajomedieval, Valladolid, Universidad de Valladolid, 1995: 131-168.

Fernández Conde, Francisco Javier, La religiosidad medieval en España. Baja Edad Media (siglos XIV-XV), Oviedo, Trea, 2011.

Fernández Suárez, Ana, Registros notariales del Archivo de la Casa de Valdecarzana (1397-1495), Oviedo, Instituto de Estudios Asturianos, 1993.

Fita, Fidel, «Concilios españoles inéditos: provincial de Braga en 1261 y nacional en Sevilla en 1478», Boletín de la Real Academia de la Historia, 22 (Madrid, 1893): 209-257.

Franchini, Enzo, Los debates literarios en la Edad Media, Madrid, Ediciones del Laberinto, 2001.

Gacto Fernández, Enrique, La filiación no legítima en el derecho histórico español, Sevilla, Universidad de Sevilla, 1969.

Gacto Fernández, Enrique, «La filiación ilegítima en la historia del derecho español», Anuario de Historia del derecho Español, 41 (Madrid, 1971): 899-944.

García y García, Antonio, Constitutiones concilii quarti Lateranensisuna cum commentariis glossatorum, Ciudad del Vaticano, Biblioteca Apostólica Vaticana, 1981a.

García y García, Antonio (dir.), Synodicon Hispanum. I, Galicia, Madrid, Biblioteca de Autores Cristianos, $1981 b$.

García y García, Antonio (dir.), Synodicon Hispanum. III, Astorga, León y Oviedo, Madrid, Biblioteca de Autores Cristianos, 1984.

García y García, Antonio (dir.), Synodicon Hispanum. IV, Ciudad Rodrigo, Salamanca y Zamora, Madrid, Biblioteca de Autores Cristianos, 1987.

García y García, Antonio (dir.), Synodicon Hispanum. V, Badajoz, Coria-Cáceres y Plasencia, Madrid, Biblioteca de Autores Cristianos, 1990. 
García y García, Antonio (dir.), Synodicon Hispanum. VI, Ávila y Segovia, Madrid, Biblioteca de Autores Cristianos, 1993.

García y García, Antonio (dir.), Synodicon Hispanum. VII, Burgos y Palencia, Madrid, Biblioteca de Autores Cristianos, 1997.

García y García, Antonio (dir.), Synodicon Hispanum. IX, Alcalá la Real (Abadía), Guadix y Jaén, Madrid, Biblioteca de Autores Cristianos, 2010.

García y García, Antonio (dir.), Synodicon Hispanum. X, Cuenca y Toledo, Madrid, Biblioteca de Autores Cristianos, 2011.

García y García, Antonio (dir.), Synodicon Hispanum. XI, Cádiz, Canarias, Cartagena, Córdoba, Granada, Málaga y Sevilla, Madrid, Biblioteca de Autores Cristianos, 2013.

Gómez, Pedro, Libro notable y santísimo tratado, compuesto y ordenado por el muy devoto pastor en la iglesia de Dios, Don Pedro el segundo deste nombre, arzobispo de la muy noble ciudad de Sevilla..., 1401-1500?, h. 1-96v, Biblioteca Nacional de España, Ms. 9299.

González Arce, José Damián, Documentos medievales de Sevilla en el Archivo Municipal de Murcia. Fueros, privilegios, ordenanzas, cartas, aranceles (siglos XIIIXV), Sevilla, Ayuntamiento de Sevilla, Servicio de Publicaciones, 2003.

González Jiménez, Manuel, A través de Sevilla y Andalucía. Estampas de Historia medieval, Sevilla, Universidad, 2011.

González, Julio, Reinado y diplomas de Fernando III. 3, Diplomas (1233-1253), Córdoba, Monte de Piedad y Caja de Ahorros, 1986.

Goñi Gaztambide, José, «Una bula de Juan XXII sobre reforma del episcopado castellano (4 junio 1318)», Hispania Sacra, 8 (Madrid, 1955): 409-413.

Guadalupe Beraza, María Luisa, Colección documental del archivo de la catedral de Salamanca I, 1098-1300, León, Centro de Estudios e Investigación San Isidoro, 2010.

Hidalgo de Cisneros Amestoy, Concepción, Fuentes jurídicas medievales del Señorío de Vizcaya. Cuadernos legales, Capítulos de la Hermandad y Fuero Viejo (1342-1506), San Sebastián, Sociedad de Estudios Vascos, 1986.

Jimeno Aranguren, Roldán, «Concubinato, matrimonio y adulterio de los clérigos: notas sobre la regulación jurídica y praxis en la Navarra medieval», Anuario de Historia del derecho español, 81 (Madrid, 2011): 543-574.

Linehan, Peter, La Iglesia española y el Papado en el siglo XIII, Salamanca, Universidad Pontificia de Salamanca, 1975.

Linehan, Peter, Las Dueñas de Zamora: secretos, estupro y poderes en la Iglesia española del siglo XIII, Barcelona, Península, 2000.

López de Ayala, Pedro, "Rimado de Palacio», en Poetas castellanos anteriores al siglo XV. Colección hecha por Don Tomás Antonio Sánchez, continuada por Don Pedro José Pidal y considerablemente aumentada e ilustrada, á vista de los códices y manuscritos antiguos por Don Florencio Janer, Madrid, Rivadeneyra, 1952.

Mansilla, Demetrio, La documentación pontificia hasta Inocencio III (965-1216), Roma, Instituto Español de Estudios Eclesiásticos, 1955. 
Martín Cea, Juan Carlos, El mundo rural castellano a fines de la Edad Media: el ejemplo de Paredes de Nava en el siglo XV, Valladolid, Junta de Castilla y León, Consejería de Cultura y Turismo, 1991.

Martínez Diez, Gonzalo, Fueros locales en el territorio de la provincia de Burgos, Burgos, Caja de Ahorros Municipal de Burgos, 1982.

Muro Abad, Juan Robert, «La castidad del clero bajomedieval en la diócesis de Calahorra», Historia, instituciones, documentos, 20 (Sevilla, 1993): 261-282.

Ortiz de Zúñiga, Diego, Anales eclesiásticos y seculares de la muy noble y muy leal ciudad de Sevilla, Madrid, Imprenta Real, 1677.

Pérez, Martín, Libro de las confesiones. Una radiografía de la sociedad medieval española. Edición crítica, introducción y notas por Antonio García y García, Bernardo Alonso Rodríguez y Francisco Cantelar Rodríguez, Madrid, Biblioteca de Autores Cristianos, 2002.

Portela Silva, María José, Documentos da catedral de Lugo. Século XIV, Santiago de Compostela, Consello da Cultura Galega, 2007.

Real Academia de la Historia (ed.), Cortes de los antiguos Reinos de León y de Castilla, publicadas por la Real Academia de la Historia. Tomo segundo, Madrid, Imprenta y Estereotipia de M. Rivadeneyra, 1863.

Real Academia de la Historia (ed.), Cortes de los antiguos Reinos de León y de Castilla, publicadas por la Real Academia de la Historia. Tomo cuarto, Madrid, Establecimiento tipográfico de los sucesores de Rivadeneyra, 1882.

Rodríguez, Ana María S. A., «Un mundo só de homens: os capitulares bracarenses e a vivencia da masculinidade nos finais da Idade Média», en Estudos em homenagem ao profesor doutor José Marques, Oporto, Universidad de Oporto, 2006: 195-209.

Rubio García, Luis, Vida licenciosa en la Murcia bajomedieval, Murcia, Academia Alfonso X el Sabio, 1991.

Rubio Semper, Agustín, «Disposiciones sobre clérigos dadas por Alfonso X», en Alfonso X El Sabio: vida, obra y época I. Actas del congreso internacional, presentación de Manuel González Jiménez; edición preparada por Juan Carlos de Miguel Rodríguez, Angela Muñoz Fernández y Cristina Segura Graiño, Madrid, Sociedad Española de Estudios Medievales, 1989: 191-197.

Rubio Semper, Agustín, Fuentes medievales sorianas. Agreda I, Soria, Diputación Provincial de Soria, 1999.

Ruiz Asencio, José María, Colección documental del archivo de la catedral de León 9, (1269-1300), León, Centro de Estudios e Investigación San Isidoro, 1994.

Sánchez de Vercial, Clemente, Sacramental, ¿Burgos?, ¿Fadrique de Basilea?, ¿1475?, Biblioteca Nacional de España, Incunables, 2055.

Sánchez Herrero, José, Concilios provinciales y sínodos toledanos en los siglos XIV y $X V$. La religiosidad cristiana del clero y pueblo, La Laguna, Universidad de La Laguna, 1976.

Sánchez Herrero, José, Las diócesis del reino de León: siglos XIV-XV, León, Centro de Estudios e Investigación «San Isidoro», 1978. 
Sánchez Herrero, José, «Amantes, barraganas, compañeras, concubinas clericales», Clío \& Crimen: Revista del Centro de Historia del Crimen de Durango, 5 (Durango, 2008): 106-137.

Talavera, Hernando de, «Breve forma de confesar», en Escritores místicos españoles. Tomo I, Hernando de Talavera, Alejo Venegas, Francisco de Osuna, Alonso de Madrid. Con un discurso preliminar de Don Miguel Mir, Madrid, Bailly Bailliere, 1911.

Tejada y Ramiro, Juan (ed.), Colección de cánones y de todos los Concilios de la Iglesia de España y de América: (en latín y castellano). III, Concilios del siglo IX en adelante, con notas e ilustraciones por Juan Tejada y Ramiro, Madrid, Imprenta de Pedro Montero, 1861.

Vaca Lorenzo, Ángel, «La peste negra en Castilla. Aportación al estudio de algunas de sus consecuencias económicas y sociales», Studia historica. Historia medieval, 2 (Salamanca, 1984): 89-107.

Velasco Bayón, Balbino, Herrero Jiménez, Mauricio, Pecharromán Cebrián, Segismundo y Montalvillo García, Julia, Colección documental de Cuéllar (934-1492), Cuéllar, Ayuntamiento de Cuéllar, 2010.

Recibido: 06/09/2016

Aprobado: 04/07/2017 